\title{
International Morphological Terminology (anatomy, histology and embryology): beyond scientific terms
}

\author{
LOSARDO, R. J. ${ }^{1,2,3 *}$, VALVERDE BARBATO DE PRATES, N. E. ${ }^{1,2,4}$, \\ ARTEAGA-MARTINEZ, M. ${ }^{1,2,5}$, GARCÍA PELÁEZ, M. I. ${ }^{1,2,5}$ and \\ CABRAL R. H. ${ }^{1,2,4}$
}

\author{
${ }^{1}$ SILAT Executive Committee, Circuito Escolar, 411 A, Copilco Universidad, Cd. Universitaria, 04360, Coyoacán, \\ CDMX, México \\ ${ }^{2}$ Pan American Association of Anatomy, Circuito Escolar, 411 A, Copilco Universidad, Cd. Universitaria, 04360, \\ Coyoacán, CDMX, México \\ ${ }^{3}$ College of Medicine, Universidad del Salvador - USAL, Tucumán, 1845, CP 1050, Ciudad de Buenos Aires, \\ Argentina \\ ${ }^{4}$ Instituto de Ciências Biomédicas - ICB, Universidade de São Paulo - USP, Av. Prof. Lineu Prestes, 1374, \\ Butantã, CEP 05508-900, São Paulo, SP, Brazil \\ ${ }^{5}$ College of Medicine, Universidad Nacional Autónoma de México - UNAM, Circuito Escolar, 411 A, Copilco \\ Universidad, Cd. Universitaria, 04360, Coyoacán, CDMX, México \\ *E-mail: ricardo.losardo@usal.edu.ar
}

\begin{abstract}
The study of the International Morphological Terminology, the creation of a dictionary or guide and its implementation is complex. The creation of SILATs meant an advance in the studying, spreading and acceptance of the international morphology in Ibero-America. However, there are some problems that have not been completely solved. This paper tries to explain some aspects that will get us closer to the understanding of those challenges, together with a possible way of solving them.
\end{abstract}

Keywords: terminology, anatomy, histology, embryology, morphology, medical education, linguistics.

\section{Introduction}

Towards the end of the 19th century, there were around 50000 names for 5000 anatomical structures worldwide (FREITAS, 2008; WERNECK and BATIGALIA, 2011). This originated a state of confusion and made scientific information exchanges a difficult task (CHAUNCEY, 1917; SKINNER, 1963; GRINBERG, 1999; NOVAK, GIOSTRI and NAGAI, 2008; WERNECK and BATIGALIA, 2011). Thus, anatomists around the world decided to meet in order to establish a universal language within anatomical sciences.

The first important effort was made by the German Anatomical Society in 1895. They founded the first committee, and over 5000 anatomical terms were unified and published in the Basel Nomina Anatomica (CHAUNCEY, 1917; FREITAS, 2008).

Since that day and a century later, anatomists have continued with their efforts. However, the results obtained are not completely satisfying. The implementation of the International Morphological Terminology in universities, hospitals and health centers is a challenge, and it is taking a lot of effort and time (MATUSZ, 2010; MEDEIROS FERNANDES, 1999; PAWLINA and DRAKE, 2009; VOGL, 2009; VASQUEZ and DEL SOL, 2014).

\section{History and Current Situation}

\subsection{International frame}

The International Federation of Associations of Anatomists, IFAA, was created in 1903 to represent anatomical societies at a global level (DIDIO and ESPERANÇA-PINA, 1992). During its $5^{\text {th }}$ Congress in England 1950, the Anatomical
Nomenclature Committee was founded. It revised and published several editions of the Nomina Anatomica.

In Brazil 1989, the Federal Committee on Anatomical Terminology (FCAT) performed a meeting, and the term "nomina" was replaced by "terminology" (FREITAS, 2008; NOVAK, GIOSTRI and NAGAI, 2008; VANDAELE and GINGRAS, 2013; WHITMORE, 2009; DUQUE PARRA and RIOS, 2013). FCAT, FICAT or FIPAT (consecutive names for the same entity) is under the supervision of IFAA and it is formed by professors who hold meetings to study morphological terminology (FEDERATIVE..., 1998, 2008, 2011, 2013).

IFAA reestablished a set of rules for the denomination of morphological structures: most of them should be named under a single term, the language employed should be Latin, the description should refer to geometry and shape and eponyms should be eliminated.

IFAA's focus is mainly scientific and has not changed since that first meeting during the $19^{\text {th }}$ century. Naming a term "official" and omitting the rest does not guarantee an immediate change in its use, because use always goes before norm (LOSARDO, VALVERDE BARBATO DE PRATES, ARTEAGA MARTINEZ et al., 2015). Terms are part of a reality and, in order to change it, morphologists should go beyond the creation of an official nomina or terminology and adopt a socio-cultural point of view.

\subsection{Pan American frame}

At a Pan American level, the Pan American Association of Anatomy (PAAA) - entity with a half century of existence (1966-2016) - echoed this problem, widened the focus and 
created the Iberian Latin American Symposia of Terminology (SILAT) in 2009 (LOSARDO, 2009; CRUZ, RODRIGUEZ, PRATES et al., 2010a, b).

SILATs are generally performed twice a year. Their headquarters vary among participating countries: Argentine, Bolivia, Brazil, Colombia, Costa Rica, Cuba, Chile, Dominican Republic, Ecuador, United States of America, El Salvador, Guatemala, Honduras, Mexico, Nicaragua, Paraguay, Peru, Uruguay and Venezuela. Some countries have made one, two or three SILATs whereas others are still planning to make one. So far, fourteen SILAT have been held:

- SILAT I: 13-16 April 2009, San José de Costa Rica. President: Prof. Dr. Rolando Cruz Gutiérrez;

- SILAT II: 15-18 September 2009, Lima, Peru. President: Prof. Dr. Germán Molina Albornoz;

- SILAT III: 26-30 April 2010, San José de Costa Rica. President: Prof. Dr. Rolando Cruz Gutiérrez;

- SILAT IV: 3-7 October 2010, São Paulo, Brazil. President: Prof. Dra. Nadir Eunice Valverde Barbato de Prates;

- SIlAT V: 25-26 October 2010, Temuco, Chile. President: Prof. Dr. Alberto Rodríguez Torres;

- SILAT VI: 13-16 April 2011, México D.F, Mexico. President: Prof. Dr. Manuel Arteaga Martínez;

- SILAT VII: 12-16 February 2012, São Paulo, Brazil. President: Prof. Dr. Richard Halti Cabral;

- SILAT VIII: 2-4 May 2012, San José de Costa Rica. President: Prof. Dr. José Luis Quirós Alpízar;

- SILAT IX: 29-30 September 2013, Huatulco, Mexico. President: Profa. Dra. María Isabel García Peláez;

- SILAT X: 16-18 July 2014, Managua, Nicaragua. President: Profa. Dra. Jamnyce Altamirano Carcache;

- SILAT XI: 19-21 November 2014, Temuco, Chile. President: Prof. Dr. Mariano del Sol Calderón;

- SILAT XII: 25-28 August 2015, San José, Costa Rica. President: Prof. Dr. Rolando Cruz Gutiérrez;

- SILAT XIII: 11-12 November 2015, Valdivia, Chile. President: Prof. Dr. Erik Gonzalo Trujillo;

- SILAT XIV: 28-30 July 2016, México D. F. México. President: Prof. Dr. Antonio Soto Paulino.

The fact that these events are held at universities gives SILAT an educating frame, for it allows not only professors to participate, but also students. Furthermore, everyone interested in morphological terminology can participate in SILATs (Figure 1).

Consequently, these meetings have several attendants, each one belonging to a different group: experts that have been participating since the first SILAT, experts that have been incorporated afterwards and are still developing their knowledge and those who have not any experience on the subject. Thus, it could be said that SILAT allows mutual nourishment among its participants and also that the number of participants and SILAT's multiplying effect increase constantly.

Furthermore, SILAT benefits from the constant participation of three Latin American experts on anatomy: Drs. Rolando Cruz
Gutiérrez (Costa Rica), José Carlos Prates (Brazil) and Alberto Rodríguez Torres (Chile). The first two professors have also been representatives of the previous FCAT. Because of their double condition, they have a better understanding of international and local problems concerning morphological terminology.

The Pan American Academy of Anatomy newly created (2010), as an extension of the Pan American Association of Anatomy, has been involved in this issue. It has awarded prizes to the best papers presented at SILAT in order to promote the study and research of morphological terms.

\section{SILAT: More Than a Scientific Meeting}

Beyond the study and translation of terminology, several activities that go beyond the symposium are performed (CRUZ, RODRIGUEZ, PRATES et al., 2010b):

1. Promotion: coordination and stimulation of the spreading and usage of the international terminology at universities;

2. Teaching: preparation of teachers on the subject;

3. Research: searching for a common scientific language for the Ibero-American scientific community. This also includes formulation of local and national terminology proposals, which are discussed in SILAT Experts Committee;

4. Publications: documentation of work in scientific and educational fields, by means of different publications: symposia reports, seminaries, conferences, round tables, brochures, journals, signatures and books;

5. Technical assessment: considering and offering at universities assistance and technical projects to cooperate on the subject.

For this reason, the creation of SILATs meant a change in the way terminology was approached. Not only do SILAT experts study and investigate terms, but also carry out spreading and educating campaigns at a local level, so that analyzed terminology can be employed. Moreover, the frequency in which SILATs are held and the kind of events they represent differ from those of the IFAA experts and gives it a broader point of view.

SILAT also encourages different kinds of research about terminology. Conferences and posters are presented during the symposium. Since its creation in 2009, the number of research papers on terminology written by Latin American authors in Spanish and Portuguese languages has raised. The subjects discussed during these symposia could be considered as a new source of inspiration for many professionals and another way of

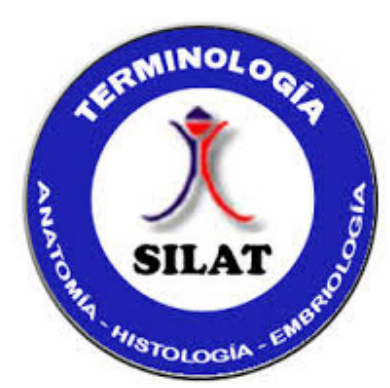

Figure 1. SILAT logo established at 10th SILAT (July 2014). 
developing their professional career. Thanks to SILAT, Latin American interest and effort to reach a unified international terminology has increased.

\section{Interdisciplinary Focus}

Although SILAT has helped to spread the international morphological terminology, there are still issues to solve. Many terms are difficult to analyze, originating discussions and debates that remain unconcluded and that have to be submitted to the IFAA, which is the highest authority in International Terminology.

SILAT experts struggle to improve the proper use of Spanish and Portuguese languages. However, despite being experts in their field, they need additional knowledge to analyze terms from other perspectives: linguistic, social and communicational (LOSARDO, VALVERDE BARBATO DE PRATES, ARTEAGA MARTINEZ et al., 2015).

In its statute, SILAT describes as one of its objectives to "study and analyze the Spanish and Portuguese translation of the International Morphological Terminology" (LOSARDO, CRUZ, RODRIGUEZ et al., 2010). In order to achieve that, it is necessary to adopt an etymological focus for a deep analysis of Latinate, Greek and Arabian roots and for its translation (MEDEIROS FERNANDES, 1999; FREITAS, 2008; SALGADO \& TRUJILLO, 2010). For this task, it is necessary the presence of specialized translators, as it was the case only in some SILATs.

Besides, a linguistic perspective is also needed to adapt those translations to Spanish and Portuguese language rules and choose the most adequate version.

A possible solution to the problems originated by the most difficult terms would be the implementation of an interdisciplinary approach. In this way, morphologists and linguists would be working together and sharing their knowledge.

\section{Discussion: Terminology as a Discipline}

Scientific discourse is used by scientists to communicate their research and knowledge. It is written in a specific language, which has to be universal for its easy and correct application (NOVAK, GIOSTRI and NAGAI, 2008). The task of improving this linguistic code belongs to terminology.

Terminology was conceived by Eugen Wüster in Vienna, around 1930. He defined it as a necessary tool for the disambiguation of scientific and technical communication and for a universal scientific understanding (CABRE, 2000).

Its study involves several disciplines:

1.Linguistics: study of the structure and evolution of languages;

2. Knowledge sciences: study of the circumstances in which knowledge emerges and the criteria that justify or invalidate it;

3. Information sciences: recompilation, organization, searching and spreading of scientific and technologic information;

4. Communication sciences: study of the communication system.
It would be reckless to ignore the knowledge offered by this discipline, which will probably contribute to solve those challenges that still exist.

\section{Conclusion}

Even though morphologists have been trying to unify morphological terminology, the problem has not been completely solved. This is because the international focus is merely scientific and other aspects that would make professors, students and health professionals adopt the international terminology are not observed.

SILAT proposes a broader and more modern point of view, adopting a socio-cultural focus and raising awareness among Latin American specialists about the importance of a compromise towards the proper use of their languages. It is for this reason that advances in the spreading of international terminology were made thorough Ibero-America.

However, in order to achieve a better result it is necessary to keep widening the point of view. A term should be approached and analyzed as a language unit, a communication vehicle, a cognitive and informative element. For this reason, the presence of language specialists is of major importance.

Terminology as a discipline started more than seventy years ago and its study involves other knowledge braches. Nevertheless, there has not been an encounter point with morphologists. Perhaps, this is the time to collect all those unsolved terms and analyze them from a linguistic, social and communicational point of view, so that a new lasting scientific, cultural and social reality can be constructed.

Acknowledgements: To Bárbara Sol Moschini, from Instituto de Enseñanza Superior en Lenguas Vivas "Juan Ramón Fernández" (Buenos Aires), for her collaboration on research, translation and final writing of this paper.

\section{References}

CABRE, M.T. Terminologie et linguistique: la théorie des portes. Terminologies Nouvelles: Terminologie et Diversité Culturelle, 2000, 21: 10-15.

CHAUNCEY, A. Anatomical names, especially the Basle Nomina Anatomica ("BNA”). New York: William \& Wood Company, 1917.

CRUZ, R., RODRIGUEZ, A., PRATES, JC., LOSARDO, RJ. and BARBATO, NEV. Simposios de Terminología. Anatomía, Histología y Embriología. International Journal of Morphology, 2010a, vol. 28, n. 1, p. 333-336.

CRUZ, R., RODRIGUEZ, A., PRATES, JC., LOSARDO, RJ. and PRATES, NEVB. Simposio Ibero-latinoamericano de Terminología Morfológica: características generales. International Journal of Morphology, 2010b, vol. 28, n. 2, p. 643-646.

DUQUE PARRA, J.E. and RIOS, J. Umbilical-spinous line: a morphological term that should be included in the anatomical terminology. Colombia Médica, 2013, vol. 44, no. 3, p. 202-204.

FEDERATIVE INTERNATIONAL PROGRAMME FOR ANATOMICAL TERMINOLOGY - FCAT. Terminologia anatomica. Stuttgart: Thieme, 1998.

FEDERATIVE INTERNATIONAL PROGRAMME FOR ANATOMICAL TERMINOLOGY - FICAT. Terminologia histologica. Philadelphia: Wolters Kluwer/Lippincott Williams \& Wilkins, 2008. 
FEDERATIVE INTERNATIONAL PROGRAMME FOR ANATOMICAL TERMINOLOGY - FIPAT. Terminologia anatomica. 2nd ed. Stuttgart: Thieme, 2011.

FEDERATIVE INTERNATIONAL PROGRAMME FOR ANATOMICAL TERMINOLOGY - FIPAT. Terminologia embryologica. Stuttgart: Thieme, 2013.

FREITAS, V. Anatomia: conceitos e fundamentos. Porto Alegre: Artmed, 2008. chap 3. Terminologia anatômica.

GRINBERG, M. Epônimos em cardiologia. homenagem e exemplo. São Paulo: Livraria Roca, 1999.

DIDIO, LJA. and ESPERANÇA-PINA, JÁ. International Federation of Associations of Anatomists - IFAA. Revista Chilena Anatomia, 1992, vol. 10, n. 2, p. 139-144.

LOSARDO, RJ. Asociación panamericana de anatomía: reseña histórica y normativas vigentes. International Journal of Morphology, 2009, vol. 27, n. 4 , p. 1345-1352.

LOSARDO, RJ., CRUZ, R., RODRIGUEZ, A., PRATES, JC. and PRATES, NEVB. Simposios Ibero-latinoamericanos de terminología morfológica (SILAT). Primeros dos años y normativas vigentes. International Journal of Morphology, 2010, vol. 28, n. 4, p. 1323-1326.

LOSARDO, RJ., VALVERDE BARBATO DE PRATES, NE., ARTEAGA MARTINEZ, M., CABRAL, RH. and GARCIA PELAEZ, MI. Terminología morfológica internacional: algo más que anatomía, histología y embriología. International Journal of Morphology, 2015, vol. 33 , n. 1, p. 400-407.

MATUSZ, P. Misleading Latin/English equivalents for some liver terms in Terminologia Anatomica. Anatomical Sciences Education, 2010, vol. 3, n. 3, p. 156-157.

MEDEIROS FERNANDES, G. Eponimia: glossários de termos epônimos em anatomia e etimologia: dicionário etimológico da nomenclatura anatômica. São Paulo: Plêiade, 1999.
NOVAK, EM. and GIOSTRI, GS. and NAGAI, A. terminologia anatômica em ortopedia. Revista Brasileira de Ortopedia, 2008, vol. 43 , n. 4 , p. 103-107.

PAWLINA, W. and DRAKE, R. Moving forward with terminologia anatomica. Anatomical Sciences Education, 2009, vol. 2, n. 3, p. 93.

SALGADO, A.G.E. and TRUJILlO, H.E. Terminología: historia e importancia en el desarrollo de las ciencias morfológicas. Forensic Oral Pathology Journal, 2010, vol. 1, no. 1, p. 9-11.

SKINNER, HA. The origin of medical terms. Baltimore: Williams \& Wilkins, 1963.

VANDAELE, S. and GINGRAS, M. Les nomenclatures anatomiques: histoire et traduction. Panacea, 2013, vol. 14, n. 38, p. 222-234.

VASQUEZ, B. and DEL SOL, M. La Terminologia Histologica en las Ciencias Médicas. International Journal of Morphology, 2014, vol. 32, n. 1, p. 375-380.

VOGL, AW. Awareness of and access to a unified Terminology by Anatomists. Anatomical Sciences Education, 2009, vol. 2, n. 3, p. 139-140.

WERNECK, AL. and BATIGALIA, F. Anatomical eponyms in Cardiology from to the 60s to the XXI century. Revista Brasileira de Cirurgia Cardiovascular; Orgao Oficial da Sociedade Brasileira de Cirurgia Cardiovascular, 2011, vol. 26, n. 1, p. 98-106.

WHITMORE, I. Terminologia Anatomica includes terms in English for all scientists writing in English. Anatomical Sciences Education, 2009, vol. 2, n. 3, p. 141. 